\title{
CARACTERIZAÇÃO HIDROQUÍMICA DAS ÁGUAS SUBTERRÂNEAS NO MUNICÍPIO DE ITU (SP)
}

\author{
Mara Akie IRITANI \\ Sueli YOSHINAGA-PEREIRA \\ Sibele EZAKI \\ Geraldo Hideo ODA \\ Luciana Martin Rodrigues FERREIRA
}

\begin{abstract}
RESUMO
Com vistas ao planejamento do uso da água subterrânea no eixo Sorocaba-Campinas, região de crescente urbanização e industrialização, realizou-se um estudo hidroquímico no Município de Itu (SP). A partir dos resultados analíticos de 50 amostras de poços tubulares profundos estudados na década de 1990, foram constatadas águas predominantemente bicarbonatadas cálcicas no Aquífero Cristalino e bicarbonatadas sódicas a cálcicas no Aquífero Tubarão. As águas foram classificadas como adequadas e boas para uso agrícola e pecuário. No entanto, para consumo humano, foram identificados poços tubulares cujas águas não atendem aos padrões bacteriológicos da Portaria de potabilidade do Ministério da Saúde (Portaria 2914, de 12/12/2011), provavelmente associados a problemas de proteção sanitária ( 5 com a presença de coliformes fecais e 13 com coliformes totais). Elevadas concentrações de ferro e/ou manganês também foram identificadas em 16 poços e devem estar relacionadas tanto a características geológicas como a problemas construtivos. Verificou-se ainda uma ocorrência anômala de fluoreto, provavelmente associada à alteração mineral de granitoides da região.
\end{abstract}

Palavras-chave: Aquífero Tubarão, Aquífero Cristalino, hidroquímica, Município de Itu.

\section{ABSTRACT}

Hydrochemical study in Itu city (São Paulo State) was performed in the 1990s as part of a hydrogeological characterization related to the planning of groundwater use in the Sorocaba-Campinas region, an area of increasing urbanization and industrialization. Analytical results of 50 well samples indicated the predominance of calcium bicarbonate water in the Crystalline Aquifer, and of sodium to calcium bicarbonate water in the Tubarão Aquifer. The waters are considered to be appropriate for agricultural use and livestock. However, for human consumption, the water of some wells is not potable and does not meet the bacteriological standards of the Health Ministry (Ordinance 2914, of 12/12/2011), which is probably associated with problems of sanitary protection (presence of fecal coliforms in 5 wells and total coliforms in 13 wells). High concentrations of iron and/or manganese have also been observed in 16 wells and may be associated with geological features or construction problems. There is an anomalous concentration of fluoride probably related to mineral alteration of granitoid rocks.

Keywords: Tubarão Aquifer, Crystalline Aquifer, hydrochemistry, municipality of Itu.

\section{INTRODUÇÃO}

O eixo Sorocaba-Campinas é caracterizado por uma acelerada expansão urbana e desenvolvimento industrial e, consequentemente, há um aumento da demanda por água, seja para abastecimento público como para outros fins. Na década de 1990, estudos do meio físico foram realizados pelo Instituto Geológico com o objetivo de subsidiar o planejamento territorial e a elaboração do Plano 
Diretor de municípios paulistas como Sorocaba (IG 1990), Itu (IG 1991, ODA 1998, ODA \& MENDES 1998) e Campinas (IG 1993), sintetizados na publicação IG (2009). A pesquisa hidrogeológica abrangida por estes estudos consistiu na caracterização do potencial produtivo dos aquíferos, na avaliação da qualidade e uso das águas, bem como no mapeamento hidrogeológico, os quais culminaram com o desenvolvimento metodológico de zoneamento de regiões com similar produtividade de águas subterrâneas.

Neste trabalho é apresentada uma caracterização hidroquímica dos aquíferos do Município de Itu e, em particular, aspectos da qualidade para os diversos usos, com base nos resultados analíticos de 50 poços amostrados em 1991. Esses dados são registros históricos que servem de referência para estudos e avaliações futuras, no que se refere às possíveis alterações da qualidade das águas subterrâneas, principalmente em decorrência do avanço da urbanização.

No período entre os anos de 1981 e 2011, a população do Município de Itu praticamente duplicou, ou seja, passou de 76.367 para 156.011 habitantes, e, consequentemente, provocou o aumento do grau de urbanização de 85,70\% (1981) para 90,16\% (1991), conforme SEADE (2012), pelo fato do município localizar-se entre dois ei- xos de conurbação: Sorocaba-Itu e Itu-Indaiatuba. A atividade industrial e o setor de serviços desempenham importante papel no desenvolvimento da economia e na expansão urbana de Itu. Em 1991, havia 329 indústrias, correspondendo a $18,39 \%$ do total de estabelecimentos do município. Nas duas últimas décadas, o número de estabelecimentos industriais aumentou para 521 (13,79\% do total de empreendimentos) (SEADE 2012).

Na década de 1990 o volume de água subterrânea captada para abastecimento público correspondia a $0,14 \%\left(40 \mathrm{~m}^{3} / \mathrm{dia}\right)$ do total captado no município (IG 1991). Na década de 2000 essa porcentagem aumentou razoavelmente, porém ainda inferior a $5 \%$, e pouco significativa em relação ao volume de água superficial (SNIS 2008). Esse aumento indica, entretanto, que o recurso hídrico subterrâneo é cada vez mais utilizado e constitui importante fonte local de abastecimento.

O Município de Itu localiza-se na porção centro-leste do Estado de São Paulo (Figura 1), distante cerca de $130 \mathrm{~km}$ da capital paulista. Seu território tem uma área de $640,7 \mathrm{~km}^{2}$ e está situado na Unidade de Gerenciamento de Recursos Hídricos - UGRHI 10, usualmente denominada de Bacias Hidrográficas dos Rios Sorocaba e Médio Tietê.

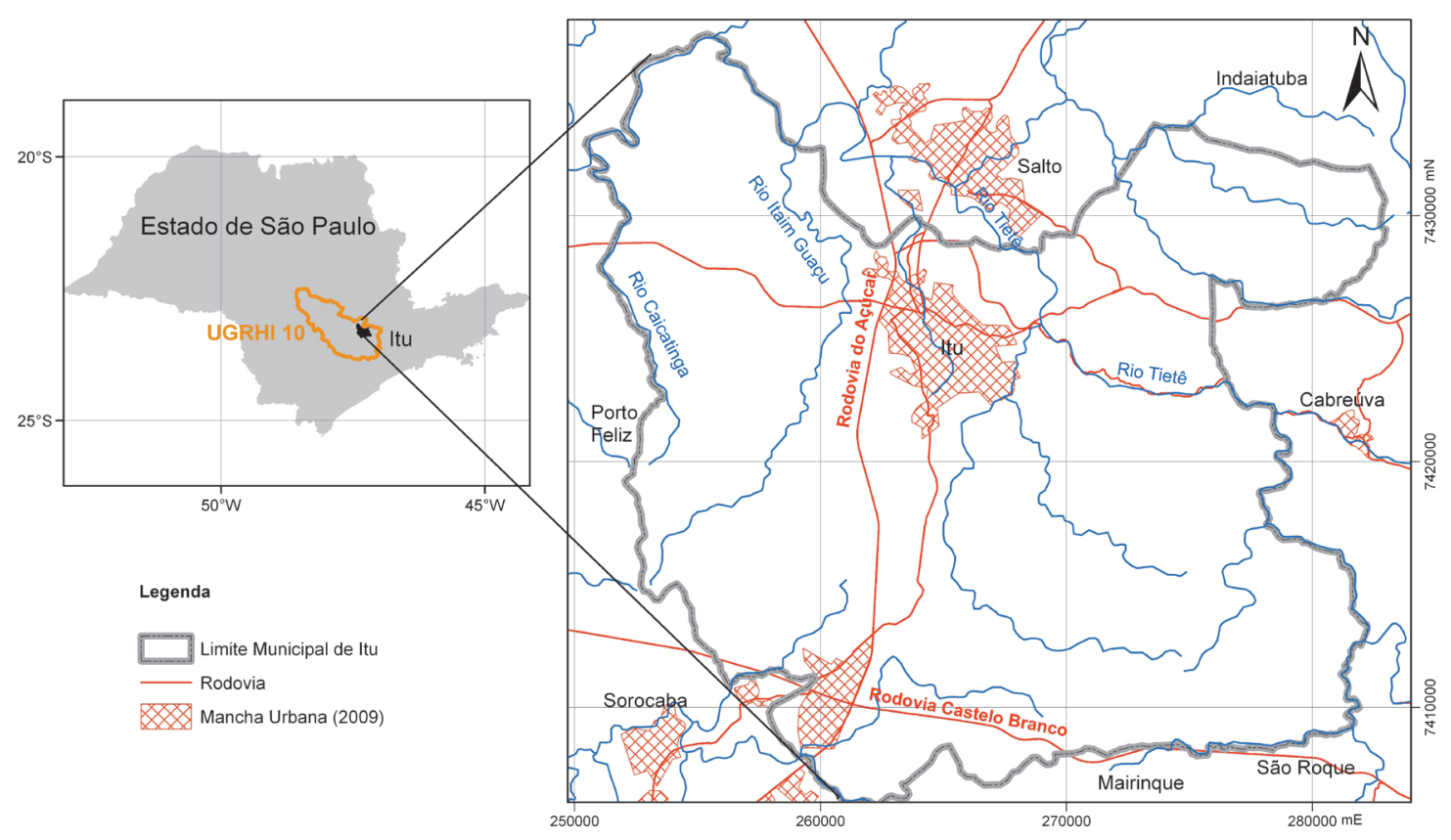

FIGURA 1 - Mapa de localização do Município de Itu. 


\subsection{Aquíferos do Município de Itu}

Na região de Itu ocorrem 2 sistemas aquíferos principais: o Cristalino (fissural, Pré-Cambriano) e o Tubarão (sedimentar predominantemente, Permocarbonífero) na borda leste da Bacia do Paraná. Aquíferos locais como os aluvionares e aqueles associados a coberturas inconsolidadas não foram abordados neste estudo.

O Aquífero Cristalino está associado a granitoides dos maciços Itu (a norte do município), Salto (nordeste) e Sorocaba (sudeste), a gnaisses e quartzitos do Complexo Itapira (a nordeste) e a metassedimentos de baixo a médio grau metamórfico do Grupo São Roque (centro-leste) (HASUI et al. 1981, 1984; JULIANI et al. 1986; GODOY 1989; PASCHOLATI 1990; IG 1991; JULIANI \& BELJAVSKIS 1995).

Por outro lado, o Aquífero Tubarão associa-se a vários tipos de sedimentos do Subgrupo Itararé, depositados em ambiente glácio-marinho, representados por intercalações e associações de arenitos, siltitos, folhelhos, argilitos, diamictitos e ritmitos (BISTRICHI et al. 1981, IG 1991, IG 2009). Na porção oeste do município ocorrem predominantemente camadas de arenitos imaturos, mal selecionados, de dimensões submétricas a métricas, intercaladas com camadas decimétricas de lamitos, siltitos, ritmitos, argilitos e diamictitos (ODA \& MENDES 2000) (Figura 2).

No contexto hidrogeológico do Estado de São Paulo, os dois aquíferos apresentam baixa disponibilidade hídrica se comparados às demais unidades hidrogeológicas (por exemplo, o Aquífero Guarani), uma vez que suas vazões médias são de $7,3 \mathrm{~m}^{3} / \mathrm{h}$ para o Aquífero Tubarão e de $7,0 \mathrm{~m}^{3} / \mathrm{h}$, para o Aquífero Cristalino na Região Metropolitana de Campinas (PEREIRA 1997). Na Região Administrativa de Sorocaba a produtividade, determinada pela capacidade específica mediana, é de 0,1 $\mathrm{m}^{3} / \mathrm{h} / \mathrm{m}$ para estes aquíferos (DAEE 1981a).

Localmente, em Itu, as capacidades específicas médias determinadas a partir de dados de 129 poços tubulares profundos (IG 1991) indicam baixa produtividade do Aquífero Tubarão $(0,12 \mathrm{~m} / \mathrm{h} / \mathrm{m})$, em função de sua heterogeneidade litológica, e valores pouco superiores no sistema misto Tubarão/ Cristalino $\left(0,19 \mathrm{~m}^{3} / \mathrm{h} / \mathrm{m}\right)$ e no Aquífero Cristalino $\left(0,39 \mathrm{~m}^{3} / \mathrm{h} / \mathrm{m}\right)$.

\section{MATERIAIS E MÉTODOS}

A amostragem de água foi idealizada de forma a abranger todo o território do Município de Itu por meio da prévia seleção de 50 poços tubulares profundos (Figura 2).

As amostras, coletadas conforme procedimentos estabelecidos por APHA/AWWA/WPCF (1985) e CETESB (1987), foram encaminhadas aos Laboratórios de Química Inorgânica e de Microbiologia da CETESB (São Paulo-SP) para as seguintes análises: $\mathrm{Ca}^{2+}, \mathrm{Mg}^{2+}, \mathrm{Na}^{+}, \mathrm{K}^{+}, \mathrm{Al}^{4+}, \mathrm{Cu}^{2+}, \mathrm{Zn}^{2+}$, $\mathrm{Cr}^{6+}$, Fe total, Mn (Espectrofotometria de absorção atômica), $\mathrm{Cl}^{-}, \mathrm{SO}_{4}{ }^{2-}, \mathrm{N}^{-\mathrm{NO}_{3}}{ }_{3}^{-} \mathrm{F}^{-}$(Cromatografia iônica líquida), alcalinidade carbonato e bicarbonato, $\mathrm{N}-\mathrm{NH}_{4}^{+}, \mathrm{N}-\mathrm{Kjedhal}$ total, dureza total, contagem padrão de bactérias (colônias $/ \mathrm{mL}$ ), coliformes totais (N.M.P./100 mL) e coliformes fecais.

Os parâmetros físico-químicos medidos em campo foram $\mathrm{pH}$ e Eh (com eletrodos de vidro e combinado de platina, DIGIMED/DM-PH-PV), temperatura do ar e da água, condutividade elétrica (DIGIMED/CD-2P), alcalinidade carbonato e bicarbonato (por meio de ensaios de titulação).

O balanço iônico (erro prático em \%) foi calculado a partir dos resultados das análises das águas, conforme procedimento proposto por CUSTÓDIO \& LLAMAS (1983). Os erros variaram de $0,74 \%$ a $37,32 \%$ e a média foi de $10,28 \%$. Amostras com erros acima de $20 \%$ ( $\mathrm{N}^{\text {os }} 12$ e 19 do Aquífero Cristalino; $\mathrm{N}^{\text {os }} 17$ e 40 do Aquífero Tubarão) foram desconsideradas.

As águas foram classificadas com base nos dados analíticos, utilizando-se os diagramas de Piper, gerados no programa AquaChem 5.1 (SCHLUMBERGER WATER SERVICES 2007). Diagramas de Stiff também foram utilizados para representar a variação espacial da composição.

A qualidade das águas para consumo humano foi avaliada comparando-se os resultados analíticos da amostragem com os padrões de potabilidade da Portaria N ${ }^{\circ} 2.914$ do Ministério da Saúde (BRASIL 2011) e do Decreto Estadual No 12.486 (SÃO PAULO 1978).

A adequabilidade das águas ao uso agrícola (irrigação) foi avaliada segundo a classificação proposta pelo United States Salinity Laboratory - USSL (USDA 1954), que considera a razão de adsorção de sódio (RAS) e a condutividade elétrica da água. Para determinação da RAS utilizou-se a seguinte equação:

$$
R A S=\frac{r N a^{+}}{\sqrt{\frac{r\left(C a^{2+}+M g^{2+}\right)}{2}}} \quad(\text { Equação 1) }
$$




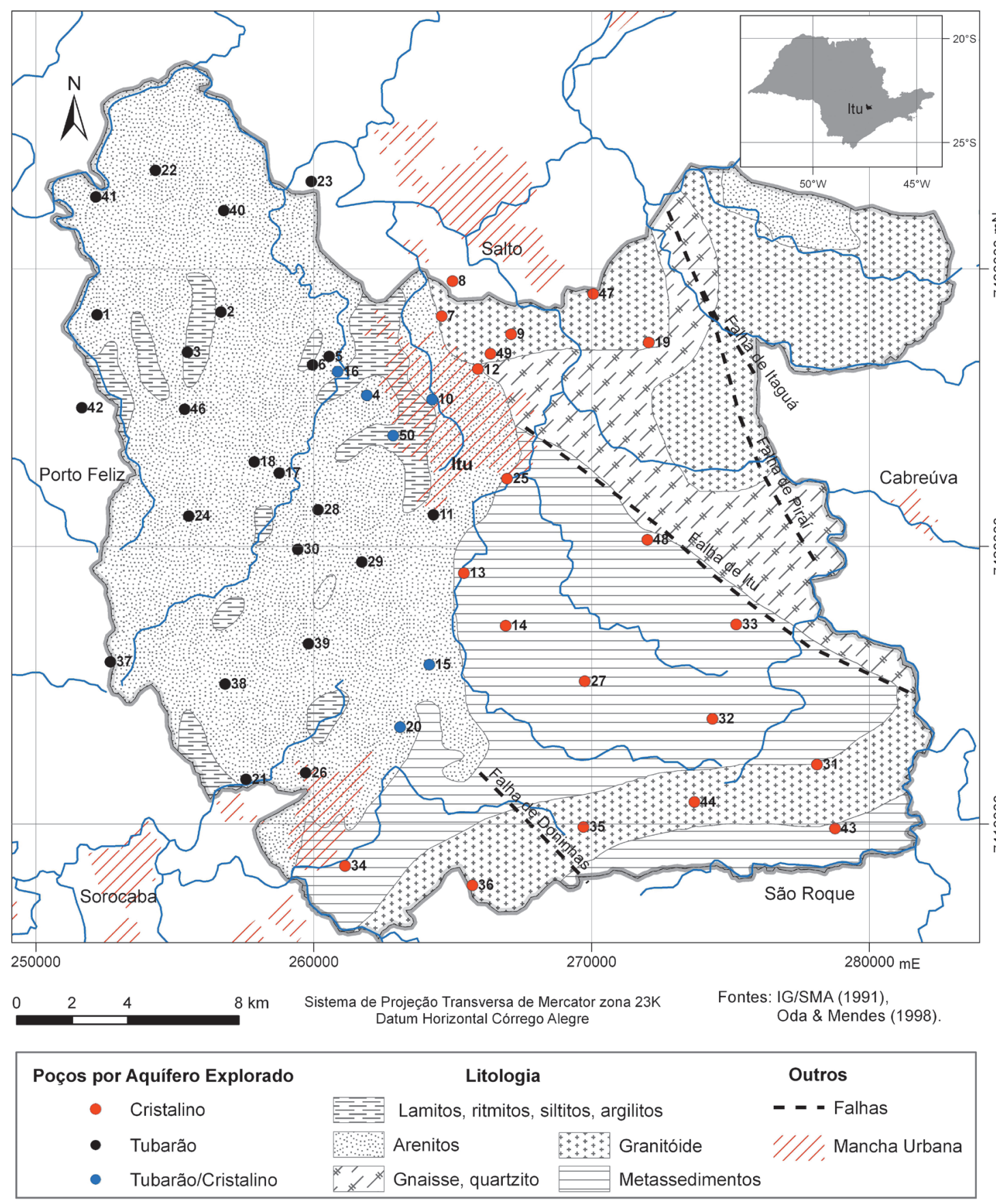

FIGURA 2 - Mapa geológico modificado do Município de Itu e localização dos poços tubulares amostrados.

A classificação do uso da água subterrânea para pecuária baseou-se na concentração dos sólidos totais dissolvidos (STD), conforme tabela 1.

O potencial de incrustação e de corrosão das águas foi calculado pelo índice de estabilidade de Rysnar (I) (CUSTÓDIO \& LLAMAS 1983), conforme a equação:
$I=2 p H_{s}-p H \quad$ (Equação 2)

onde:

$\mathrm{pH}_{\mathrm{s}}$ é o $\mathrm{pH}$ de saturação, calculado por meio de nomograma de Hoover-Langelier, e

$\mathrm{pH}$ é o $\mathrm{pH}$ medido em campo.

A classificação das águas segundo os valores de I encontra-se na tabela 2. 
TABELA 1 - Classificação das águas subterrâneas para uso pecuário (LOGAN 1965).

\begin{tabular}{c|c}
\hline $\begin{array}{c}\text { Sólidos Totais Dissolvidos } \\
\left(\mathrm{mg} \mathrm{dm}^{-3}\right)\end{array}$ & $\begin{array}{c}\text { Classificação segundo } \\
\text { uso para gado }\end{array}$ \\
\hline$<2500$ & Boa \\
2500 a 3500 & Satisfatória \\
3500 a 4500 & Pobre \\
$>4500$ & Insatisfatória \\
\hline
\end{tabular}

TABELA 2 - Classificação das águas subterrâneas quanto ao índice de estabilidade de Rysnar.

\begin{tabular}{c|c}
\hline $\begin{array}{c}\text { Indice de Estabilidade } \\
\text { de Rysnar }\end{array}$ & Classificação \\
\hline$>9,0$ & Potencialmente corrosiva \\
7,0 a 9,0 & Corrosiva \\
5,0 a 7,0 & Incrustante ou corrosiva \\
4,0 a 5,0 & Potencialmente incrustante \\
\hline
\end{tabular}

\section{RESULTADOS E DISCUSSÕES}

Considerando as litologias às quais o aquífero explotado está associado e os aspectos construtivos dos poços, estes foram agrupados em: Tubarão $(\mathrm{T})$ - poços que atravessam somente o Grupo Tubarão-Subgrupo Itararé; Cristalino $(\mathrm{C})$ - poços que penetram somente no Embasamento Cristalino; Misto (TC - Tubarão/Cristalino) - poços que atravessam e que recebem a contribuição dos Aquíferos Cristalino e Tubarão; neste caso um dos aquíferos explotados deve corresponder, no mínimo, a $20 \%$ da profundidade total do poço.

Considerando todos os 50 poços tubulares representativos da área de estudo, 20 explotam água do Aquífero Cristalino (12 em granitoides e $8 \mathrm{em}$ metassedimentos do Grupo São Roque), 23 do Aquífero Tubarão, 6 são mistos e 1 poço não possui definição do aquífero bombeado (amostra $\mathrm{N}^{\circ} 45$ ).

$\mathrm{Na}$ tabela 3 são apresentadas as seguintes informações sobre os poços tubulares amostrados: localização, profundidade, uso da água, tipo de usuário e data de coleta da amostra. Cada poço recebeu uma identificação numérica referente ao Cadastro de Poços do Instituto Geológico/SMA.

A maior parte dos poços tem a água utilizada para fins sanitários, tanto em área urbana como rural; 11 são destinados ao uso agropecuário; 11 para produção industrial e 3 para o abastecimento público.
Os poços dos aquíferos Cristalino, Tubarão e Misto apresentam, respectivamente, valores médios de profundidade de $125,8 \mathrm{~m}, 140 \mathrm{~m}$ e $149,8 \mathrm{~m}$, e medianas de $120 \mathrm{~m}, 121 \mathrm{~m}$ e $145 \mathrm{~m}$.

3.1 Caracterização físico-química, química e bacteriólogica das águas subterrâneas

Os resultados da composição química e físico-química das águas dos poços do Município de Itu estão apresentados nas tabelas 4, 5 e 6.

Em geral, as águas podem ser interpretadas como pouco mineralizadas, em função dos valores de condutividade elétrica (CE) de suas amostras. A CE média e a mediana das águas do Aquífero Cristalino são, respectivamente, $147,10 \mu \mathrm{S} \mathrm{cm}^{-1}$ e $132,00 \mu \mathrm{S} \mathrm{cm} ~^{-1}$ (Tabela 5), valores condizentes aos apresentados por DAEE (1981a), que registrou médias inferiores a $260,00 \mu \mathrm{S} \mathrm{cm} \mathrm{cm}^{-1}$, sendo consideradas fracamente salinas. As águas do Aquífero Tubarão apresentam CE média de $265,40 \mu \mathrm{S} \mathrm{cm}^{-1}$ e mediana de $351,00 \mu \mathrm{S} \mathrm{cm}^{-1}$. São também consideradas fracamente salinas, quando comparadas às médias obtidas para as regiões de Campinas $\left(<350,00 \mu \mathrm{S} \mathrm{cm}^{-1}\right.$, DAEE 1981b), Sorocaba $\left(<790,00 \mu \mathrm{S} \mathrm{cm}^{-1}\right.$, DAEE 1981a) e Médio Tietê $\left(<560,00 \mu \mathrm{S} \mathrm{cm}^{-1}\right.$, DINIZ 1990). As águas dos poços mistos apresentam CE média de $363,70 \mu \mathrm{S}$ $\mathrm{cm}^{-1}$ (Tabela 5) e, portanto, próxima à $\mathrm{CE}$ do Aquífero Tubarão. 
TABELA 3 - Identificação e informações sobre os poços tubulares amostrados no Município de Itu.

\begin{tabular}{|c|c|c|c|c|c|c|c|c|}
\hline $\begin{array}{c}N^{o} \\
\text { amostra }\end{array}$ & $N^{o}$ Poço IG & Usuário & $\begin{array}{c}\text { UTME } \\
\text { (m) }\end{array}$ & $\begin{array}{c}\text { UTMN } \\
(\mathrm{m})\end{array}$ & Aquífero & $\begin{array}{c}\text { Profund. } \\
\text { (m) }\end{array}$ & $\begin{array}{c}\text { Data } \\
\text { Coleta }\end{array}$ & Uso da Água \\
\hline 1 & 7433 & Sitio & 252200 & 7428350 & $\mathrm{~T}$ & 170 & $29 / 10 / 1990$ & Saneam./Particular \\
\hline 2 & 7484 & Camping & 256650 & 7428450 & $\mathrm{~T}$ & 108 & 29/10/1990 & Saneam./ Particular \\
\hline 3 & 7458 & Sitio & 255450 & 7427000 & $\mathrm{~T}$ & 120 & $29 / 10 / 1990$ & Pecuária \\
\hline 4 & 7559 & Chácara & 261900 & 7425450 & $\mathrm{TC}^{*}$ & 100 & $30 / 10 / 1990$ & Saneam./ Particular \\
\hline 5 & 7544 & Cerâmica & 260550 & 7426850 & $\mathrm{~T}$ & 107 & $30 / 10 / 1990$ & Indústria \\
\hline 6 & 7531 & Chácara & 259950 & 7426550 & $\mathrm{~T}$ & 100 & $30 / 10 / 1990$ & Saneam./ Particular \\
\hline 7 & 7605 & Cerâmica & 264600 & 7428300 & $\mathrm{C}$ & 63 & $31 / 10 / 1990$ & Indústria \\
\hline 8 & 7613 & Clube & 264992 & 7429562 & $\mathrm{C}$ & 133 & $31 / 10 / 1990$ & \\
\hline 9 & 7635 & Camping & 267100 & 7427650 & $\mathrm{C}$ & 115 & $31 / 10 / 1990$ & Saneam./ Particular \\
\hline 10 & 7598 & Indústria & 264250 & 7425300 & $\mathrm{TC}$ & 180 & 05/11/1990 & Indústria \\
\hline 11 & 7601 & Indústria & 264300 & 7421150 & $\mathrm{~T}$ & 121 & $05 / 11 / 1990$ & Indústria \\
\hline 12 & 7636 & Chácara & 265900 & 7426400 & $\mathrm{C}$ & 137 & 05/11/1990 & Saneam./ Particular \\
\hline 13 & 7617 & Haras & 265400 & 7419050 & $\mathrm{C}$ & 82 & 06/11/1990 & Saneam./ Particular \\
\hline 14 & 7631 & Fazenda & 266900 & 7417150 & $\mathrm{C}$ & 160 & 06/11/1990 & Saneam./ Particular \\
\hline 15 & 7594 & Sitio Rincão & 264150 & 7415750 & $\mathrm{TC}$ & 150 & 06/11/1990 & Indústria \\
\hline 16 & 7545 & Indústria & 260850 & 7426300 & $\mathrm{TC}$ & 222 & 07/11/1990 & Indústria \\
\hline 17 & 7507 & Fazenda & 258750 & 7422650 & $\mathrm{~T}$ & 102 & 07/11/1990 & Agropec. \\
\hline 18 & 7500 & Haras & 257850 & 7423050 & $\mathrm{~T}$ & 100 & 07/11/1990 & Pecuária \\
\hline 19 & 7664 & Indústria & 272050 & 7427350 & $\mathrm{C}$ & & $11 / 08 / 1990$ & Indústria \\
\hline 20 & 7582 & Indústria & 263100 & 7413500 & $\mathrm{TC}^{*}$ & 107 & $11 / 08 / 1990$ & Indústria \\
\hline 21 & 7495 & Posto combustível & 257550 & 7411615 & $\mathrm{~T}$ & 155 & $11 / 08 / 1990$ & Saneam./ Particular \\
\hline 22 & 7451 & Sitio & 254300 & 7433550 & $\mathrm{~T}$ & 150 & $11 / 12 / 1990$ & Pecuária \\
\hline 23 & 7528 & Haras & 259900 & 7433150 & $\mathrm{~T}$ & & $11 / 12 / 1990$ & \\
\hline 24 & 7459 & Chácara & 255500 & 7421100 & $\mathrm{~T}$ & 173 & $11 / 12 / 1990$ & Saneam./ Particular \\
\hline 25 & 7624 & Serviço de Água & 266950 & 7422450 & $\mathrm{C}$ & 180 & $13 / 11 / 1990$ & $\begin{array}{l}\text { Abastecimento } \\
\text { Público }\end{array}$ \\
\hline 26 & 7522 & Serviço de Água & 259700 & 7411850 & $\mathrm{~T}$ & 123 & 13/11/1990 & $\begin{array}{l}\text { Abastecimento } \\
\text { Público }\end{array}$ \\
\hline 27 & 7462 & Fazenda & 269750 & 7415150 & $\mathrm{C}$ & 120 & $13 / 11 / 1990$ & Saneam./ Particular \\
\hline 28 & 7532 & Cerâmica & 260150 & 7421330 & $\mathrm{~T}$ & 196 & $26 / 11 / 1990$ & Indústria \\
\hline 29 & 7554 & Cerâmica & 261720 & 7419450 & $\mathrm{~T}$ & 100 & $26 / 11 / 1990$ & Indústria \\
\hline 30 & 7518 & Indústria & 259420 & 7419900 & $\mathrm{~T}$ & 203 & $26 / 11 / 1990$ & Indústria \\
\hline 31 & 7677 & Condomínio & 278100 & 7412150 & $\mathrm{C}$ & & $27 / 11 / 1990$ & Saneam. \\
\hline 32 & 7669 & Fazenda & 274350 & 7413800 & $\mathrm{C}$ & & $27 / 11 / 1990$ & Saneam./ Particular \\
\hline 33 & 7670 & Fazenda & 275200 & 7417200 & $\mathrm{C}$ & & 27/11/1990 & Saneam./ Particular \\
\hline 34 & 7546 & Sitio & 261120 & 7408500 & $\mathrm{C}$ & 120 & $28 / 11 / 1990$ & Pecuária \\
\hline 35 & 7654 & Fazenda & 269700 & 7409900 & $\mathrm{C}$ & 176 & $28 / 11 / 1990$ & Pecuária \\
\hline 36 & 7620 & Sitio & 265700 & 7407800 & $\mathrm{C}$ & 100 & 28/11/1990 & Agrícola \\
\hline 37 & 7439 & Sitio & 252680 & 7415850 & $\mathrm{~T}$ & & 29/11/1990 & \\
\hline 38 & 7483 & Fazenda & 256800 & 7415050 & $\mathrm{~T}$ & 100 & 29/11/1990 & Agropec. \\
\hline 39 & 7524 & Fazenda & 259800 & 7416500 & $\mathrm{~T}$ & 178 & 29/11/1990 & Agropec. \\
\hline 40 & 7492 & Sitio & 256750 & 7432100 & $\mathrm{~T}$ & & $12 / 03 / 1990$ & Saneam./ Particular \\
\hline 41 & 7431 & Sitio & 252150 & 7432600 & $\mathrm{~T}$ & 100 & $12 / 03 / 1990$ & Saneam./ Particular \\
\hline 42 & 7425 & Chácara & 251650 & 7425000 & $\mathrm{~T}$ & & $12 / 03 / 1990$ & \\
\hline 43 & 7678 & Sitio & 278750 & 7409850 & $\mathrm{C}$ & 100 & $12 / 04 / 1990$ & Pecuária \\
\hline 44 & 7667 & Chácara & 273700 & 7410800 & $\mathrm{C}$ & & $12 / 04 / 1990$ & \\
\hline 45 & & Condomínio & & & ND & & $12 / 04 / 1990$ & Saneam./ Particular \\
\hline 46 & 7457 & Fazenda & 255350 & 7424950 & $\mathrm{~T}$ & 262 & $12 / 05 / 1990$ & Pecuária \\
\hline 47 & 7656 & Fazenda & 270050 & 7429100 & $\mathrm{C}$ & 100 & $12 / 05 / 1990$ & Saneam./ Particular \\
\hline 48 & 7663 & Fazenda & 272000 & 7420250 & $\mathrm{C}$ & 179 & $12 / 05 / 1990$ & Saneam./ Particular \\
\hline 49 & 7583 & Serviço de Água & 266350 & 7426950 & $\mathrm{C}$ & 122 & $12 / 06 / 1990$ & $\begin{array}{l}\text { Abastecimento } \\
\text { Público }\end{array}$ \\
\hline 50 & 7581 & Chácara & 262850 & 7424000 & $\mathrm{TC}^{*}$ & 140 & $12 / 06 / 1990$ & Saneam./ Particular \\
\hline
\end{tabular}

Aquífero explotado: T - Tubarão; C - Cristalino; TC - Tubarão/Cristalino; ND - Não definido; *Inferido 
TABELA 4 - Composição físico-química e microbiológica das águas subterrâneas dos poços analisados.

\begin{tabular}{|c|c|c|c|c|c|c|c|c|c|c|c|}
\hline $\begin{array}{c}N^{o} \\
\text { amostra }\end{array}$ & $p H$ & $p H_{s}$ & $I$ & $\begin{array}{c}E h \\
(m V)\end{array}$ & $\begin{array}{c}C E \\
\left(\mu S c m^{-1}\right)\end{array}$ & $\begin{array}{c}S T D \\
\left(m g d m^{-3}\right)\end{array}$ & $\begin{array}{l}\text { Temp. } \\
\left({ }^{\circ} \mathrm{C}\right)\end{array}$ & $R A S$ & $\begin{array}{c}\text { Contagem } \\
\text { padrão de } \\
\text { bactéria } \\
\text { (colonia/mL) }\end{array}$ & $\begin{array}{c}\text { Coliformes } \\
\text { totais } \\
\text { (N.M.P./ } \\
100 \mathrm{~mL} \text { ) }\end{array}$ & $\begin{array}{c}\text { Coliformes } \\
\text { fecais } \\
\text { (N.M.P./ } \\
100 \mathrm{~mL} \text { ) }\end{array}$ \\
\hline & $5-10^{* *}$ & & & & & & & & & Ausentes* & Ausentes* \\
\hline 1 & 7,27 & 8,26 & 9,25 & $-23,0$ & 251,00 & 163,15 & 23,0 & 0,24 & 2300 & ausentes & ausentes \\
\hline 2 & 7,53 & 8,30 & 9,07 & $-31,0$ & 317,00 & 206,05 & 23,5 & 3,16 & 430 & ausentes & ausentes \\
\hline 3 & 6,25 & 9,00 & 11,80 & 36,0 & 123,00 & 79,95 & 23,5 & 0,70 & 5 & ausentes & ausentes \\
\hline 4 & 7,35 & 8,40 & 9,45 & $-19,0$ & 419,00 & 272,35 & 25,0 & 6,42 & $>6500$ & ausentes & ausentes \\
\hline 5 & 7,44 & 7,85 & 8,26 & $-24,0$ & 451,00 & 293,15 & 23,5 & 2,23 & 790 & ausentes & ausentes \\
\hline 6 & 6,45 & 8,65 & 10,90 & $+23,0$ & 198,00 & 128,70 & 24,0 & 1,46 & 1 & ausentes & ausentes \\
\hline 7 & 6,80 & 8,05 & 9,30 & $+8,0$ & 283,00 & 183,95 & 23,5 & 0,76 & 0 & ausentes & ausentes \\
\hline 8 & 6,60 & 8,10 & 9,60 & $+14,0$ & 243,00 & 157,95 & 24,0 & 0,30 & 1300 & ausentes & ausentes \\
\hline 9 & 6,20 & 8,45 & 10,70 & $+33,0$ & 231,00 & 150,15 & 23,0 & 0,84 & 630 & ausentes & ausentes \\
\hline 10 & 6,78 & 7,95 & 9,12 & $+7,0$ & 558,00 & 362,70 & 24,0 & 1,48 & 3700 & ausentes & ausentes \\
\hline 11 & 7,53 & 8,10 & 8,67 & $-24,0$ & 458,00 & 297,70 & 23,5 & 2,49 & 1000 & 30 & ausentes \\
\hline 12 & 5,85 & 10,70 & & $+63,0$ & 171,00 & 111,15 & 24,0 & 0,57 & 560 & ausentes & ausentes \\
\hline 13 & 5,77 & 9,45 & 13,10 & $+68,0$ & 56,00 & 36,40 & 22,0 & 0,32 & 270 & 110 & 2 \\
\hline 14 & 7,43 & 8,55 & 9,67 & $-23,0$ & 131,00 & 85,15 & 23,0 & 0,46 & 2 & ausentes & ausentes \\
\hline 15 & 6,66 & 8,85 & 11,00 & $+18,0$ & 133,00 & 86,45 & 23,5 & 0,59 & 1 & ausentes & ausentes \\
\hline 16 & 7,04 & 7,85 & 8,66 & $-5,0$ & 577,00 & 375,05 & 22,5 & 2,75 & 180 & ausentes & ausentes \\
\hline 17 & 6,42 & 8,55 & & $+32,0$ & 274,00 & 178,10 & 22,5 & 1,04 & 80 & ausentes & ausentes \\
\hline 18 & 8,40 & 7,95 & 7,50 & $-11,0$ & 449,00 & 291,85 & 23,5 & 0,65 & 90 & ausentes & ausentes \\
\hline 19 & 5,53 & 9,70 & & $+78,0$ & 3,80 & 2,47 & 22,5 & 0,48 & 2 & ausentes & ausentes \\
\hline 20 & 6,64 & 9,57 & 12,50 & $+16,0$ & 70,00 & 45,50 & 22,5 & 0,61 & 2200 & ausentes & ausentes \\
\hline 21 & 6,83 & 7,95 & 9,07 & $+10,0$ & 284,00 & 184,60 & 23,0 & 1,30 & 1800 & ausentes & ausentes \\
\hline 22 & 7,28 & 8,10 & 8,92 & $-35,0$ & 295,00 & 191,75 & 23,0 & 0,57 & $>6500$ & $>1600$ & 27 \\
\hline 23 & 4,82 & 8,75 & 12,70 & $+123,0$ & 161,00 & 104,65 & 23,5 & 0,55 & $>6500$ & 500 & 17 \\
\hline 24 & 4,56 & 9,35 & 14,10 & $+140,0$ & 112,00 & 72,80 & 23,5 & 0,43 & 120 & ausentes & ausentes \\
\hline 25 & 7,54 & 8,20 & 8,86 & $-27,0$ & 260,00 & 169,00 & 23,0 & 2,39 & $>6500$ & $>1600$ & ausentes \\
\hline 26 & 6,70 & 8,65 & 10,60 & $+17,0$ & 134,00 & 87,10 & 25,0 & 1,12 & 3300 & 900 & ausentes \\
\hline 27 & 6,26 & 9,55 & 12,80 & $+40,0$ & 65,00 & 42,25 & 22,5 & 0,50 & 2300 & $>1600$ & ausentes \\
\hline 28 & 6,98 & 9,25 & 11,50 & $-8,0$ & 235,00 & 152,75 & 25,0 & 1,61 & 240 & 23 & ausentes \\
\hline 29 & 7,44 & 8,10 & 8,76 & $-33,0$ & 273,00 & 177,45 & 24,0 & 1,47 & 120 & ausentes & ausentes \\
\hline 30 & 7,04 & 9,45 & 11,90 & 0,0 & 208,00 & 135,20 & 24,5 & 1,46 & 830 & 30 & 8 \\
\hline 31 & 5,73 & 10,10 & 14,50 & $+68,0$ & 56,00 & 36,40 & 22,7 & 0,52 & 32 & ausentes & ausentes \\
\hline 32 & 6,30 & 9,45 & 12,60 & $+34,0$ & 71,00 & 46,15 & 21,2 & 0,35 & 4 & ausentes & ausentes \\
\hline 33 & 6,06 & 9,45 & 12,80 & $+50,0$ & 67,00 & 43,55 & 23,0 & 0,14 & 230 & 80 & ausentes \\
\hline 34 & 6,43 & 8,70 & 11,00 & $+0,24$ & 172,00 & 111,80 & 23,0 & 0,83 & $>6500$ & 50 & ausentes \\
\hline 35 & 7,21 & 8,40 & 9,59 & $-0,13$ & 215,00 & 139,75 & 22,0 & 0,82 & 370 & ausentes & ausentes \\
\hline 36 & 6,28 & 9,35 & 12,40 & $+41,0$ & 101,00 & 65,65 & 22,0 & 0,62 & 9 & ausentes & ausentes \\
\hline 37 & 5,93 & 10,50 & 15,10 & $+53,0$ & 25,00 & 16,25 & 23,0 & 0,34 & 1100 & ausentes & ausentes \\
\hline 38 & 7,70 & 8,25 & 8,80 & $-41,0$ & 238,00 & 154,70 & 23,0 & 2,49 & 570 & 130 & 130 \\
\hline 39 & 6,77 & 8,60 & 10,40 & $-5,0$ & 149,00 & 96,85 & 24,0 & 0,85 & 610 & ausentes & ausentes \\
\hline 40 & 7,72 & 8,30 & & $-41,0$ & 230,00 & 149,50 & 22,5 & 6,76 & 910 & ausentes & ausentes \\
\hline 41 & 7,03 & 7,85 & 8,67 & $-3,0$ & 470,00 & 305,50 & 23,0 & 1,07 & $>6500$ & ausentes & ausentes \\
\hline 42 & 7,65 & 8,15 & 8,65 & $-39,0$ & 364,00 & 236,60 & 21,5 & 1,06 & 4 & ausentes & ausentes \\
\hline 43 & 5,38 & 10,60 & 15,80 & $+95,0$ & 34,00 & 22,10 & 21,5 & 0,22 & 58 & ausentes & ausentes \\
\hline 44 & 6,47 & 8,80 & 11,10 & $+29,0$ & 133,00 & 86,45 & 22,0 & 0,43 & 970 & ausentes & ausentes \\
\hline 45 & 6,40 & 8,90 & 11,40 & $+34,0$ & 116,00 & 75,40 & 22,0 & 0,19 & 510 & 50 & ausentes \\
\hline 46 & 7,15 & 8,65 & 10,20 & $-17,0$ & 406,00 & 263,90 & 23,5 & 5,24 & 230 & ausentes & ausentes \\
\hline 47 & 6,25 & 9,70 & 13,20 & $+43,0$ & 79,00 & 51,35 & 23,0 & 0,64 & 18 & ausentes & ausentes \\
\hline 48 & 7,92 & 8,45 & 8,98 & $-57,0$ & 237,00 & 154,05 & 22,0 & 2,18 & 29 & ausentes & ausentes \\
\hline 49 & 7,99 & 8,40 & 8,81 & $-58,00$ & 334,00 & 217,10 & 22,0 & 4,00 & 61 & ausentes & ausentes \\
\hline 50 & 7,34 & 7,90 & 8,46 & $-22,0$ & 425,00 & 276,25 & 23,5 & 2,14 & 190 & ausentes & ausentes \\
\hline
\end{tabular}

Limite de potabilidade: *Portaria MS No 2914 (2011); **Decreto Estadual № 12.486 (1978), NTA-60 - águas de consumo alimentar $\mathrm{pH}_{\mathrm{s}}$ : $\mathrm{pH}$ de saturação; I: Índice de saturação de Rysnar; CE: Condutividade elétrica; STD: Sólidos totais dissolvidos; RAS: Razão de adsorção de sódio; N.M.P. - número mais provável. 
TABELA 5 - Valores médios e medianos de pH e de condutividade elétrica das águas subterrâneas.

\begin{tabular}{c|ccc|ccc}
\hline & \multicolumn{3}{|c|}{$p H$} & \multicolumn{3}{c}{$C E\left(\mu S \mathrm{~cm}^{-1}\right)$} \\
\hline Aquifero & Tubarão & Cristalino & Tub./Crist. & Tubarão & Cristalino & Tub./Crist. \\
\hline mínimo & 4,56 & 5,38 & 6,64 & 25,0 & 3,8 & 70,0 \\
máximo & 8,40 & 7,99 & 7,35 & 470,0 & 334,0 & 577,0 \\
média & 6,91 & 6,50 & 6,97 & 265,4 & 147,1 & 363,7 \\
desvio padrão & 0,89 & 0,76 & 0,36 & 123,4 & 95,2 & 214,3 \\
mediana & 7,04 & 6,29 & 6,91 & 251,0 & 132,0 & 422,0 \\
número de poços & 23 & 20 & 6 & 23 & 20 & 6 \\
\hline
\end{tabular}

As águas dos poços perfurados em granitoides apresentam características semelhantes àquelas explotadas dos metassedimentos do Grupo São Roque (metarenitos, metarritmitos, metassiltitos, metargilitos, etc.).

Em relação ao pH, as águas do Aquífero Tubarão estão próximas à neutralidade (média $=6,91$ ) e caracterizam um ambiente menos oxidante (Eh médio de $+4,3 \mathrm{mV}$ ) que o do Aquífero Cristalino, que apresenta $\mathrm{pH}$ inferior $($ média $=6,50)$ e Eh positivo (média $=+29,90 \mathrm{mV}$ ). Os poços mistos possuem valores médios de $\mathrm{pH}=6,97$ e de $\mathrm{Eh}=$ $-0,83 \mathrm{mV}$ e se assemelham ao Aquífero Tubarão (Tabela 5).

A análise dos resultados dos elementos químicos maiores revela que as águas são predominantemente bicarbonatadas e possuem maior concentração de sódio como íon dominante no Aquífero Tubarão, e de cálcio no Aquífero Cristalino.

Além disso, o pH, a condutividade elétrica e a composição química das águas dos poços mistos (TC) assemelham-se às àguas do Aquífero Tubarão (Tabelas 5 e 6); igualmente, manteve-se a tendência de valores mais elevados de $\mathrm{Na}^{+}$e de $\mathrm{pH}$ das águas dos sistemas mistos.

\subsection{Classificação hidroquímica}

O estudo das águas subterrâneas executado pelo DAEE na Região Administrativa 4 - Sorocaba (DAEE 1981a) utilizou a composição química de 91 poços profundos, dentre os quais 18 correspondiam ao Aquífero Cristalino e 30 ao Aquífero Tubarão. As águas do Aquífero Cristalino foram classificadas como bicarbonatadas cálcicas $(89 \%)$ e sódicas (11\%), enquanto as do Aquífero Tubarão, em sua maioria, eram bicarbonatadas sódicas $(66,7 \%)$, seguidas de cálcicas ou magnesianas $(30 \%)$ e, em pequena proporção $(3,3 \%)$, cloretadas sódicas.
Os resultados do atual estudo, direcionado apenas para o Município de Itu, mostram que as águas do Aquífero Cristalino são predominantemente classificadas como bicarbonatadas cálcicas (Ca-Na- $\mathrm{HCO}_{3}, \mathrm{Ca}-\mathrm{HCO}_{3}$ ), seguidas de tipos sódicos $\left(\mathrm{Na}-\mathrm{Ca}-\mathrm{HCO}_{3}\right)$, conforme diagrama de Piper (Figura 3). No Aquífero Tubarão ocorrem águas bicarbonatadas sódicas $\left(\mathrm{Na}-\mathrm{HCO}_{3}, \mathrm{Na}-\mathrm{Ca}-\mathrm{HCO}_{3}\right)$, cálcicas $\left(\mathrm{Ca}-\mathrm{Na}-\mathrm{HCO}_{3}, \mathrm{Ca}-\mathrm{Mg}-\mathrm{Na}-\mathrm{HCO}_{3}\right)$ e, ocasionalmente, magnesianas ( $\left.\mathrm{Mg}-\mathrm{Na}-\mathrm{Ca}-\mathrm{HCO}_{3}\right)$, em concordância com o estudo regional do DAEE (1981a). Os tipos predominantes de água nos poços mistos (Tubarão/Cristalino) são similares aos dos aquíferos Tubarão e Cristalino.

$\mathrm{Na}$ figura 4 visualiza-se a distribuição espacial dos tipos hidroquímicos da área de estudo. Na porção leste-sudeste, no domínio das rochas do Embasamento Cristalino, há predomínio das águas bicarbonatadas cálcicas. A oeste, prevalecem águas bicarbonatadas sódicas associadas principalmente aos aquíferos Tubarão e Misto. Essa variação composicional das águas também foi observada por VIDAL (2002) e VIDAL et al. (2005) nas regiões de Campinas-Sumaré a Tietê-Boituva e por EZAKI (2011) em Salto. Esses autores também registraram o aumento dos valores de condutividade elétrica rumo ao interior (oeste) do estado e nas áreas de descarga (rio Tietê em Salto), acompanhando o sentido dos fluxos subterrâneos regionais.

$\mathrm{Na}$ porção oeste-noroeste do Município de Itu também se constata o aumento da salinidade das águas, associado à zona de descarga dos aquíferos nas porções topográficas mais baixas, onde se encaixam o rio Tietê e seus afluentes (rio Itaim Guaçu e ribeirão Caiacatinga) (Figura 5). Nessa região, independentemente do aquífero explotado, a água subterrânea apresenta composição mais sódica, como observado, por exemplo, nas amostras 5 e 11 no Aquífero Tubarão, 4, 10, 16 e 50 nos poços mistos e 25 e 49 no Aquífero Cristalino (Tabela 6). 


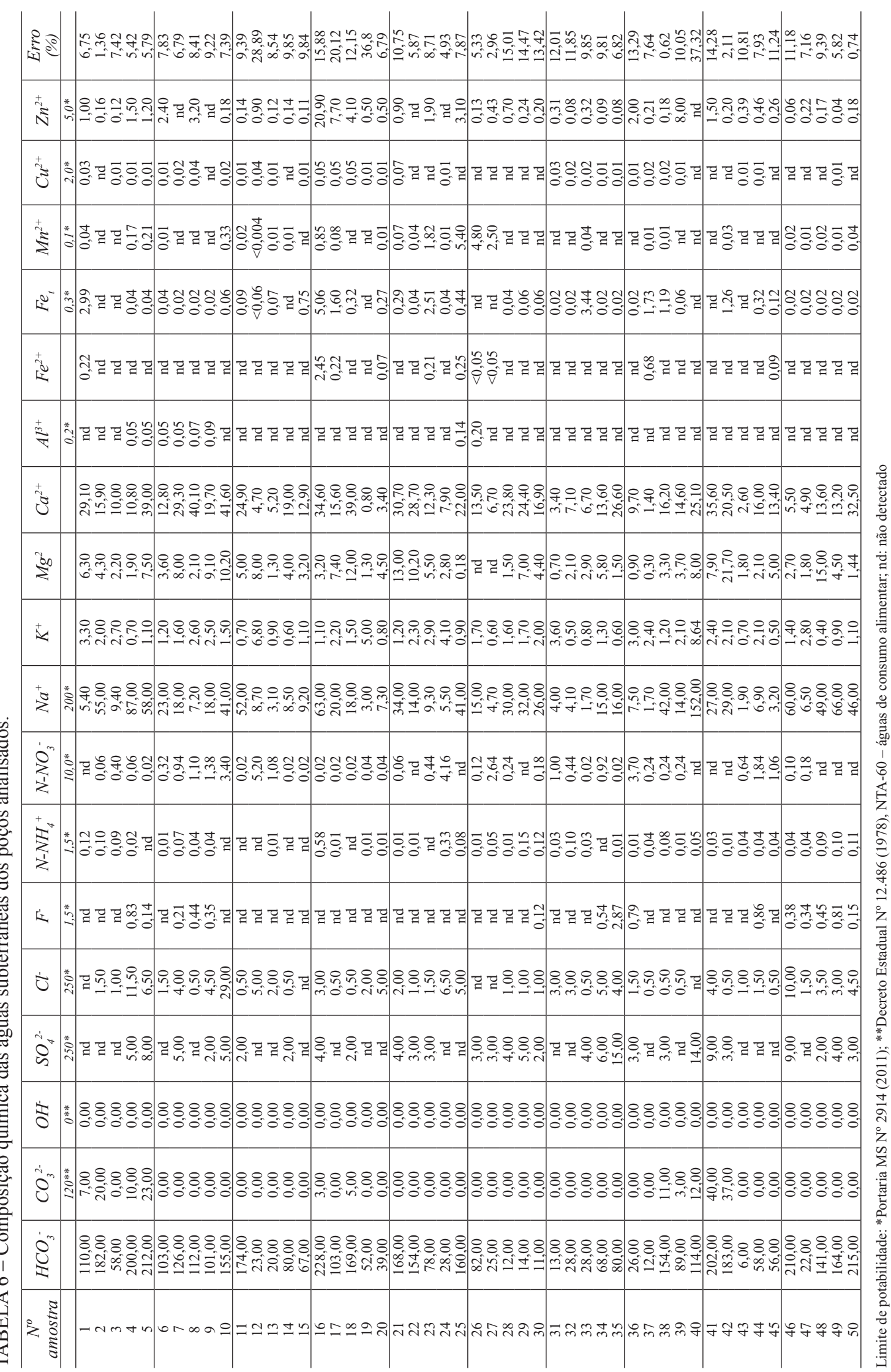




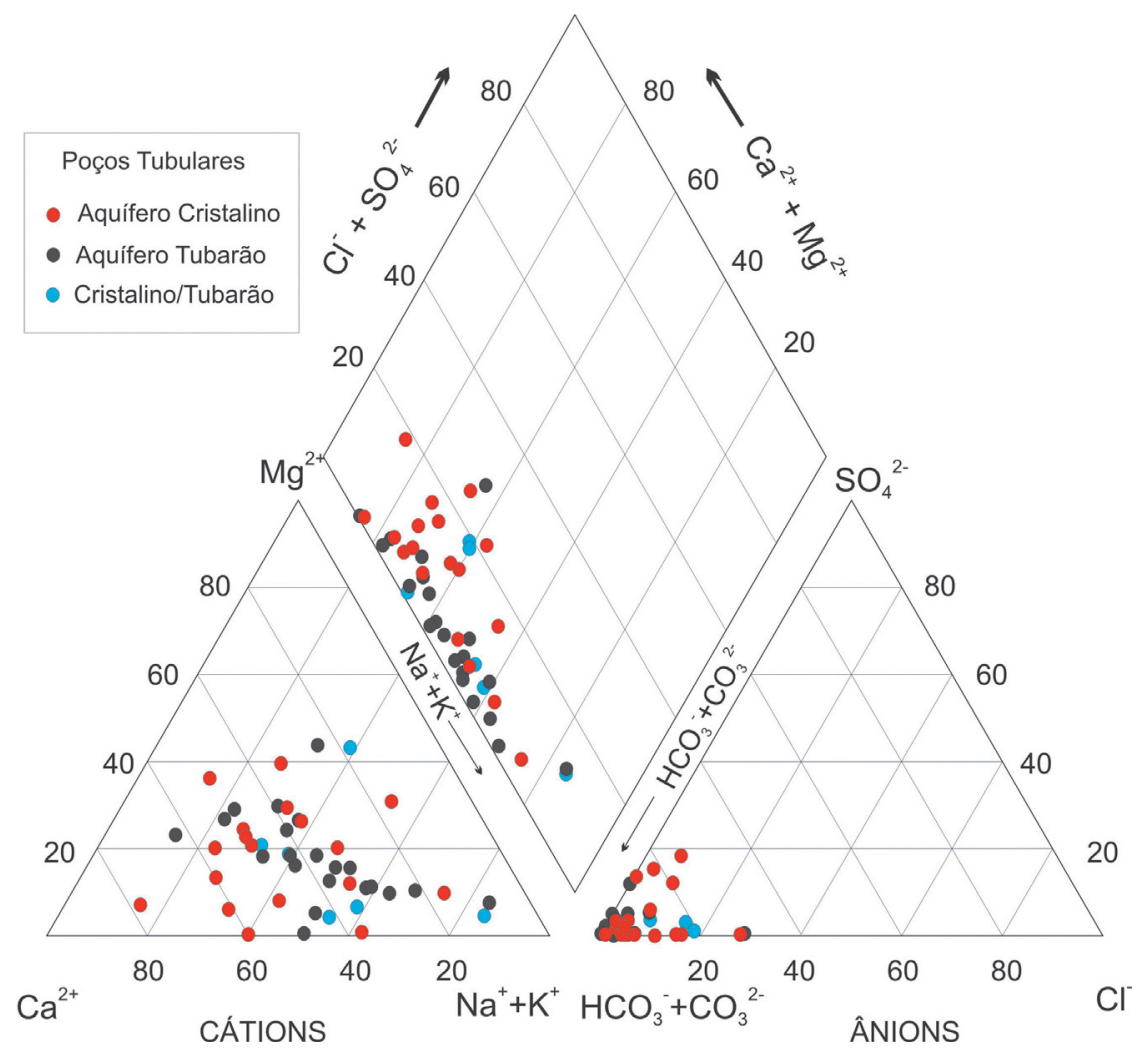

FIGURA 3 - Classificação hidroquímica das águas dos aquíferos pelo Diagrama de Piper.

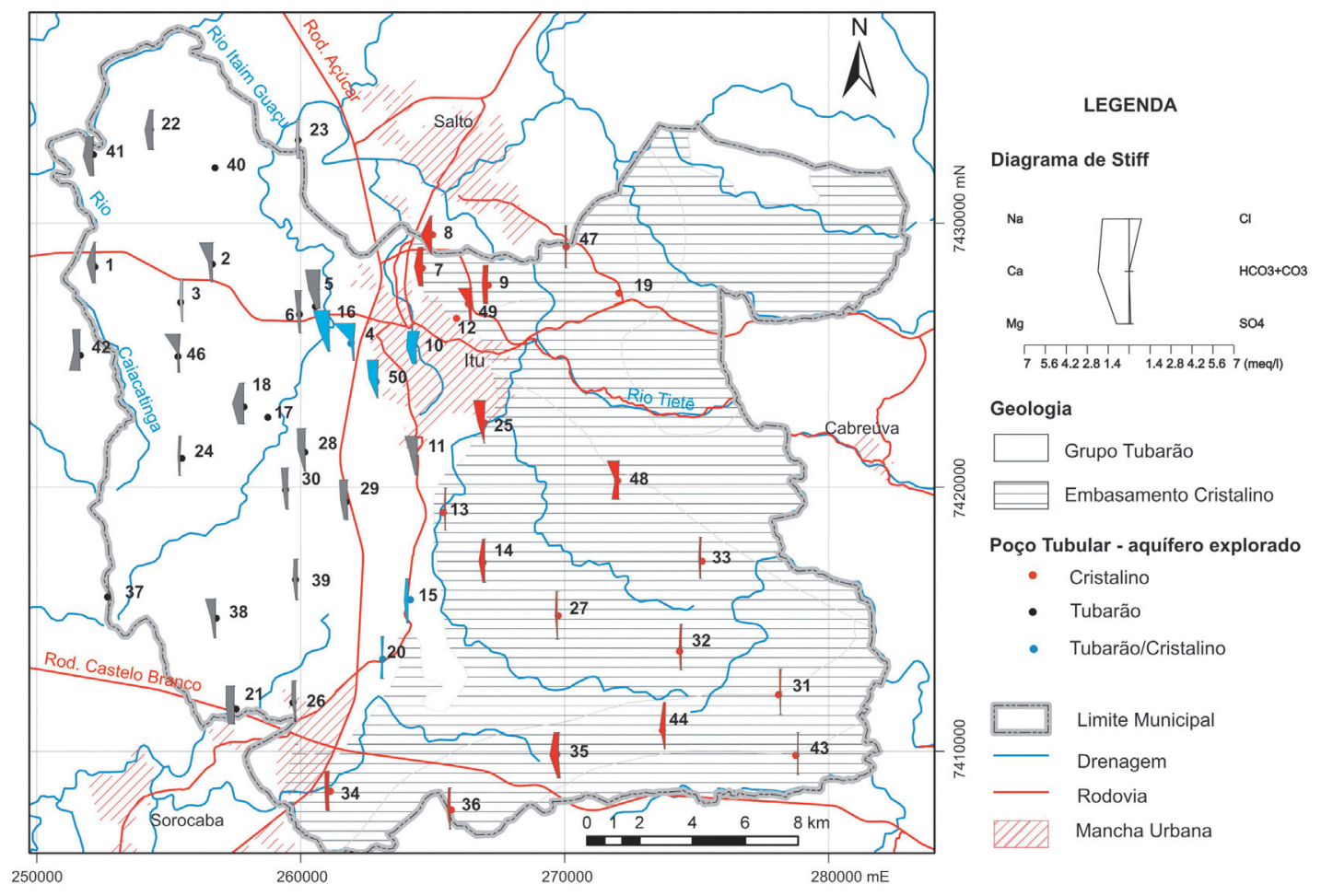

FIGURA 4 - Distribuição espacial dos tipos hidroquímicos de água subterrânea, classificados pelo Diagrama de Stiff. 


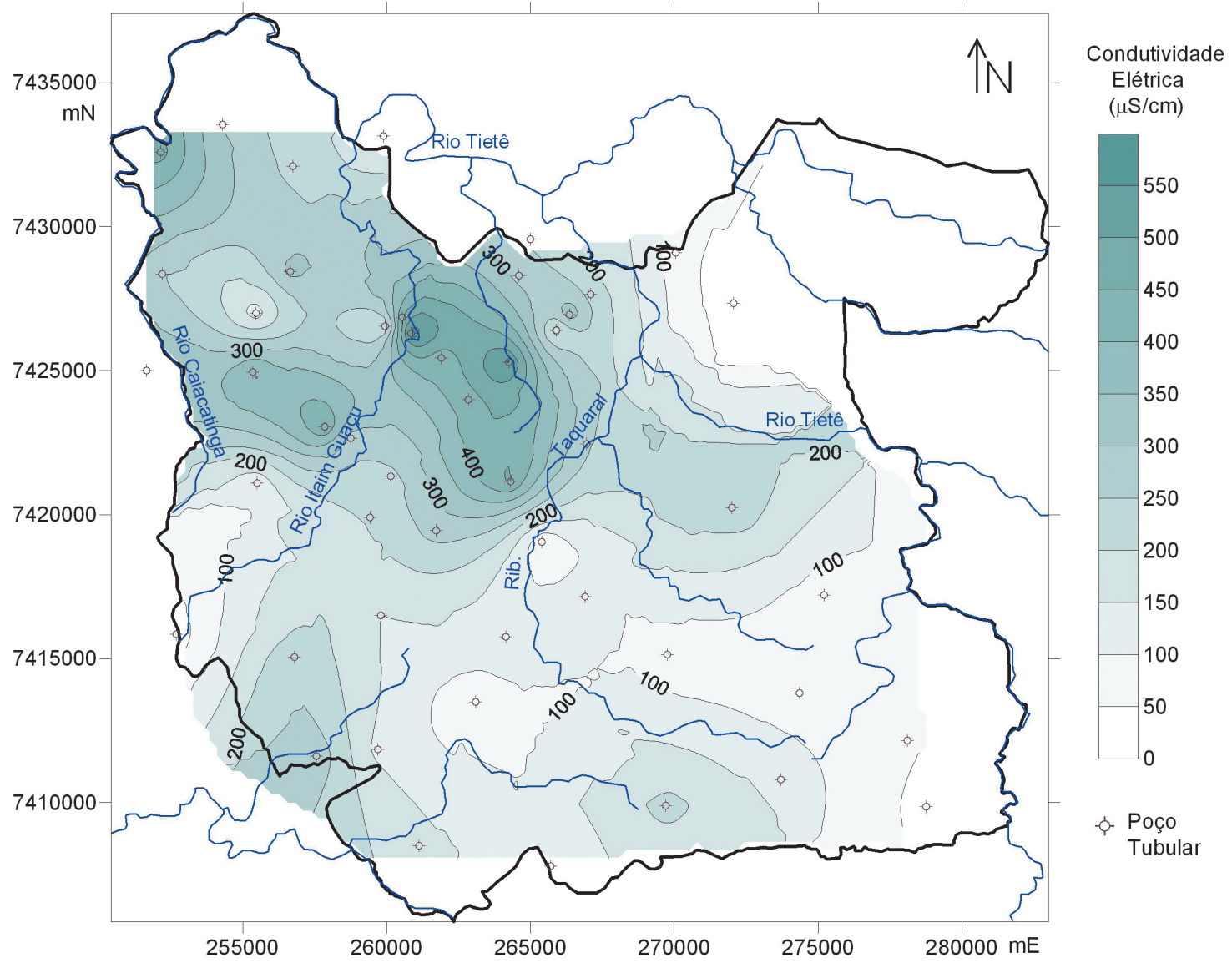

FIGURA 5 - Condutividade elétrica das águas subterrâneas do Município de Itu.

\subsection{Qualidade das águas}

Para o consumo humano os resultados analíticos mostram que as águas estudadas apresentam-se, com algumas exceções, dentro dos limites de potabilidade, considerando os parâmetros das tabelas 4 e 6 . Em 13 poços (amostras $\mathrm{N}^{\text {os }} 11,13,22,23$, $25,26,27,28,30,33,34,38$ e 45$)$ as águas não são potáveis porque não atendem aos padrões bacteriológicos de coliformes totais e fecais (Figura 6). Em 15 poços as contagens-padrão de bactérias são elevadas (valores acima dos limites de 1.000 N.M.P./100 mL) e a inspeção, proteção e/ou desinfecção do sistema são recomendadas.

A presença de coliformes é um indicador da existência de possíveis microrganismos patogênicos que podem causar doenças pela ingestão de água. Ela representa, portanto, uma alteração na qualidade da água e indica a necessidade de análises mais frequentes para se avaliar a sanidade dos poços tubulares profundos (contaminados ou não contaminados).
As concentrações de ferro e manganês estão acima do valor máximo permitido em, respectivamente, 9 e 7 amostras de água dos poços. $\mathrm{O}$ ferro total apresenta-se com teor muito elevado nas amostras Nos $1,16,23,33$ e atinge até $5,06 \mathrm{mg} \mathrm{dm}^{-3}$, assim como o teor de manganês das amostras Nos 23,25 , 26 e 27 , que atingiu o valor máximo de $5,40 \mathrm{mg} \mathrm{dm}^{-3}$ (Tabela 6). Essas concentrações devem estar relacionadas às características mineralógicas e químicas das formações geológicas da região que, em condições redutoras, como observado na maioria dos poços da região, favorece a solubilização de $\mathrm{Fe}^{2+} \mathrm{e}$ $\mathrm{Mn}^{2+}$. Problemas relacionados à qualidade construtiva dos poços tubulares ou de contaminação por outras fontes também devem ser investigados.

A presença destes íons metálicos em águas naturais normalmente não acarreta problemas à saúde, mas pode afetar as suas características organolépticas devido à aparência e ao gosto intragável; no uso doméstico causam manchas em roupas e utensílios sanitários. Esses íons podem precipitar-se como óxidos-hidróxidos nas tubulações da rede 


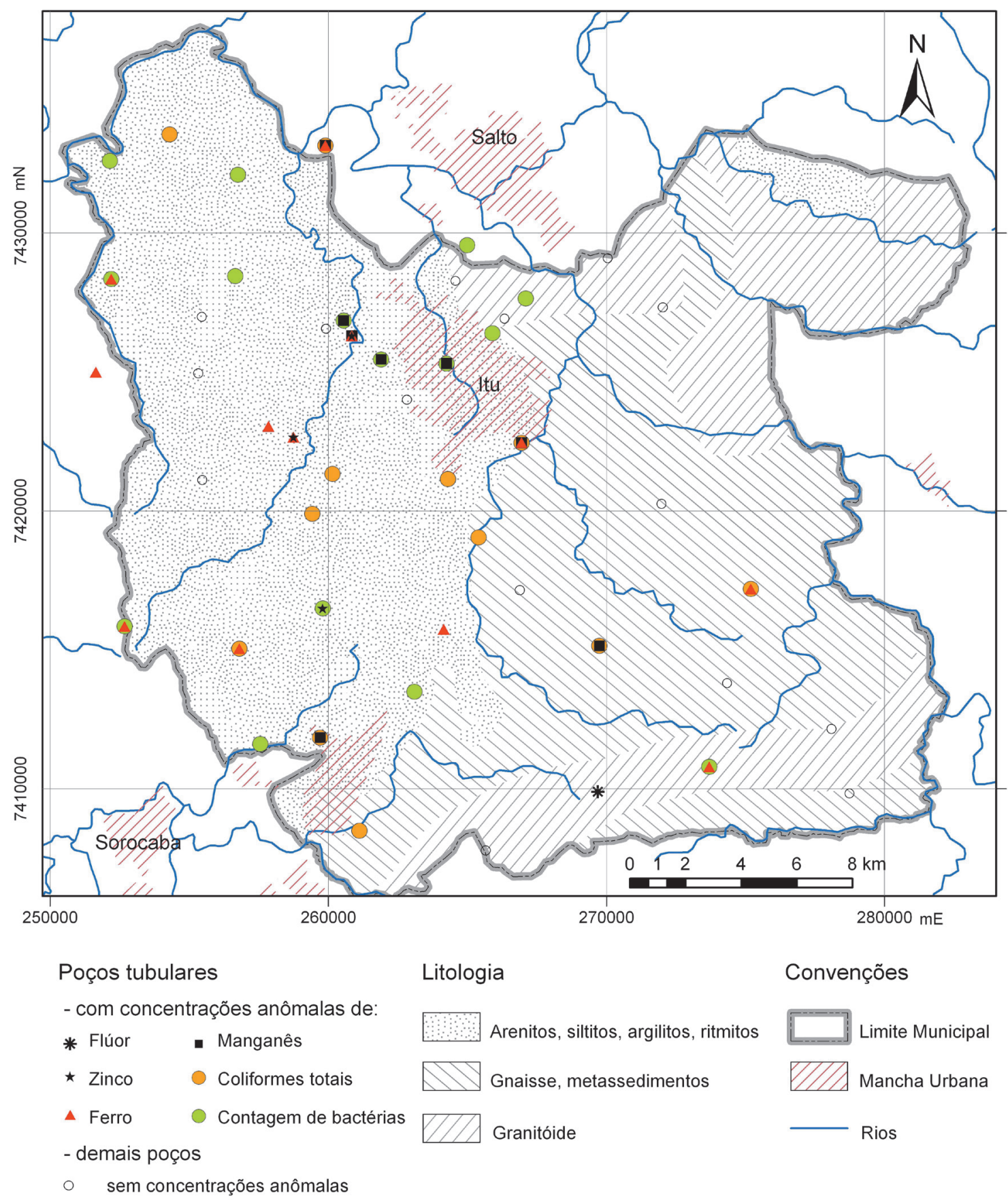

FIGURA 6 - Poços que apresentam concentrações anômalas de alguns parâmetros de qualidade da água.

de distribuição, bem como permitem o crescimento de ferro-bactérias ou bactérias que concentram o manganês, dando origem ao desconforto de sabor, odor e turbidez na distribuição de água (CCME 1999, WHO 2003).

A amostra № 35 (Aquífero Cristalino) apresenta elevada concentração de fluoreto (Tabela 6,
Figura 6). A ingestão constante dessas águas pode causar riscos à saúde, como a doença fluorose esqueletal ou dentária. A presença de fluoreto pode estar associada à indústria cerâmica, produção de alumínio e fertilizantes (rochas fosfáticas), fabricação de sabões e detergentes, preparação de couros, entre outras fontes potenciais. O poço está situado em área 


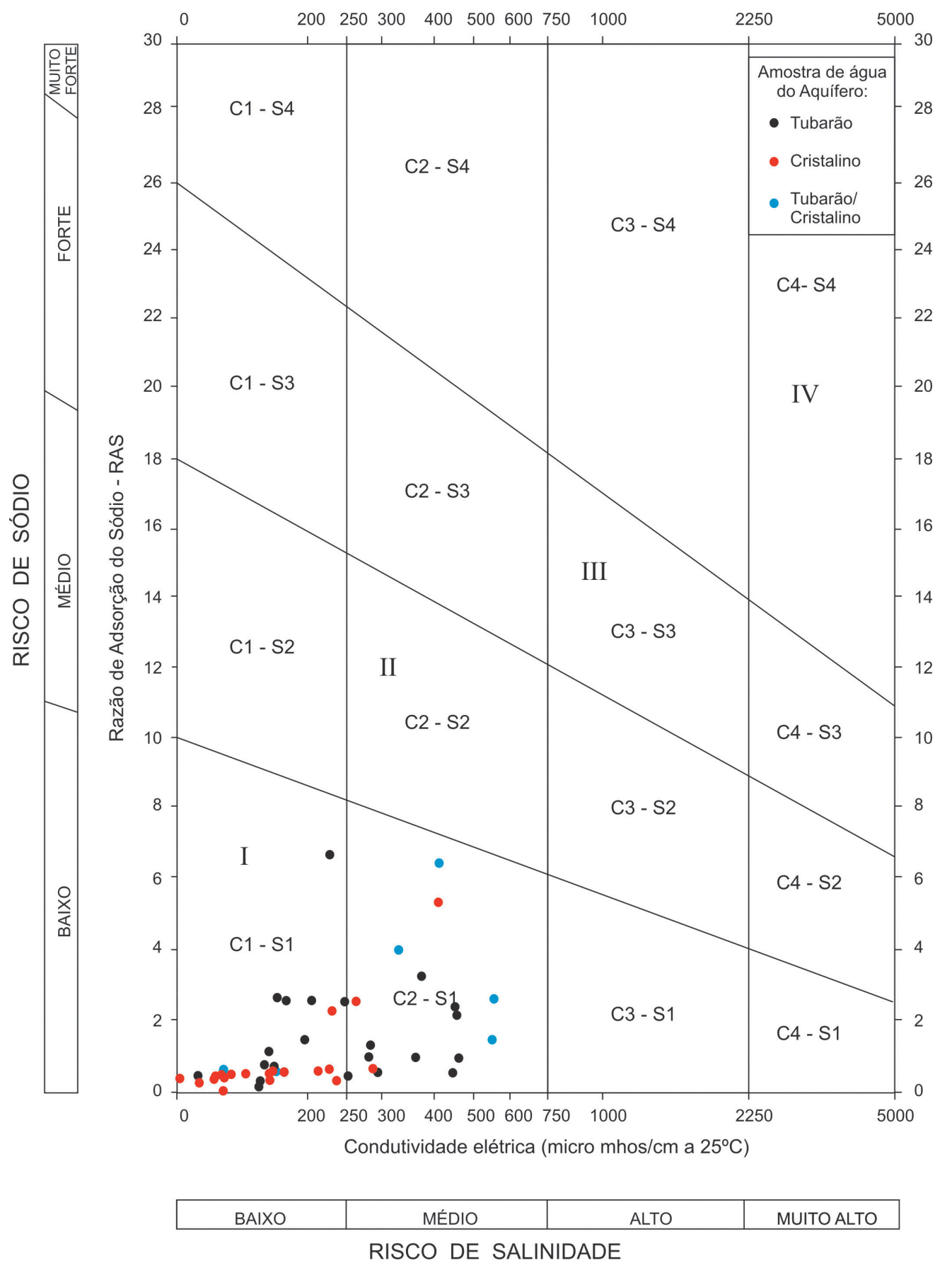

FIGURA 7 - Classificação das águas de irrigação do United States Salinity Laboratory (USDA 1954).

rural e, portanto, afastado de atividades industriais. Assim, a hipótese mais provável para sua origem está associada à alteração e hidrólise de minerais enriquecidos em flúor, sob condições específicas de $\mathrm{pH}$, temperatura, alcalinidade, e outras relações físico-químicas e químicas entre a rocha hospedeira e a água subterrânea que a percola. EZAKI (2011) considerou que a presença de flúor nas águas subterrâneas como ocorrência natural está associada com a alteração de biotitas dos granitos de Salto.

Em relação ao nitrato, apenas a amostra $\mathrm{N}^{\circ}$ 12 (Aquífero Cristalino) apresentou um teor acima 
do Valor de Alerta ( $5 \mathrm{mg} \mathrm{dm}^{-3} \mathrm{~N}^{-\mathrm{NO}_{3}}{ }_{3}^{-}$) estabelecido pela CETESB (CETESB 2010). Vale destacar, entretanto, que os teores das amostras $\mathrm{N}^{\text {os }} 10,24$ e 36, embora não ultrapassem o Valor de Alerta, já apresentam concentrações acima de $3 \mathrm{mg} \mathrm{dm}^{-3}$ $\mathrm{N}-\mathrm{NO}_{3}^{-}$, muito acima do valor mediano observado nas demais amostras $\left(0,21 \mathrm{mg} \mathrm{dm}^{-3} \mathrm{~N}^{-\mathrm{NO}_{3}}{ }^{-}\right)$. Isso pode ser indicativo da influência da atividade antrópica sobre a qualidade das águas.

A contaminação pela presença de zinco foi registrada nas amostras $\mathrm{N}^{\text {os }} 16$ e 39 , uma vez que os teores ultrapassaram o valor de potabilidade. A primeira amostra (16), coletada em um poço localizado em indústria eletrônica, registrou, além de zinco, elevadas concentrações de ferro e manganês. As outras amostras foram coletadas em poços situados em área rural.

Os valores de Razão de Adsorção de Sódio (RAS) das amostras de água indicam que o risco de sodificação provocado pelo uso da água em irrigação de solos é considerado baixo (S1). O risco de salinidade, em termos de condutividade elétrica, varia de baixo $(\mathrm{C} 1)$ a médio $(\mathrm{C} 2)$. Conforme o Diagrama para Classificação das Águas de Irrigação do USSL (United States Salinity LaboratoryUSSL), a combinação desses dois atributos determina a adequação das águas para uso agrícola. $\mathrm{Na}$ área estudada, as águas enquadram-se nas classes C1-S1 e C2-S1 (Figura 7), consideradas adequadas ao uso agrícola, sem qualquer restrição para o uso na irrigação e, portanto, podem ser utilizadas em quaisquer culturas onde os solos possuem lixiviação moderada.

O mesmo pode ser admitido no caso do uso pecuário, uma vez que as águas da região apresentam baixos valores de sólidos totais dissolvidos, geralmente inferiores a $300 \mathrm{mg} \mathrm{dm}^{-3}$.

A análise do potencial de incrustação e/ou corrosão mostra que as águas de Itu possuem uma evidente característica corrosiva. Do total de 46 amostras com índice de estabilidade Rysnar (I) calculado, 13 apresentaram resultado corrosivo (entre 7,0 e 9,0), enquanto as demais indicam águas potencialmente corrosivas $(>9,0)$. Nesse último caso, recomenda-se a manutenção constante dos poços e sistemas de bombeamento e adução, visando o prolongamento da vida útil dos equipamentos.

\section{CONCLUSÕES}

A interpretação dos resultados analíticos de 50 amostras de água de poços tubulares no Município de Itu (SP) permite agrupá-las em 2 tipos hidroquímicos: um associado ao Aquífero Cristalino e outro ao Aquífero Tubarão. No primeiro classificam-se como águas bicarbonatadas cálcicas, enquanto no segundo como bicarbonatadas sódicas a cálcicas. Os poços mistos dos Aquíferos Tubarão/ Cristalino recebem maior influência das rochas sedimentares do Grupo Tubarão-Subgrupo Itararé.

As águas, em geral, são fracamente mineralizadas, mas possuem uma tendência de aumentar a condutividade elétrica no sentido do fluxo subterrâneo, ou seja, em direção às principais drenagens da região (rios Tietê e seus afluentes principais).

Os resultados mostram claramente a alteração da qualidade em função dos parâmetros microbiológicos, e indicam a necessidade de maior proteção sanitária e uma eficaz manutenção dos poços, tanto na área urbana como na rural. A presença de zinco em elevadas concentrações indica os efeitos negativos da atividade antrópica na qualidade das águas de dois poços. Denota-se, portanto, a necessidade de monitoramento da qualidade das águas desses poços.

As elevadas concentrações de íons ferro e manganês devem estar, possivelmente, associadas às características geológicas da região ou mesmo a problemas construtivos dos poços. A ocorrência de elevada concentração de fluoreto em um poço pode ser interpretada como anomalia geoquímica associada à hidrólise mineral. Sugere-se, portanto, o acompanhamento e investigação de fontes potenciais de poluição para se determinar a origem, seja natural ou antrópica, desses elementos.

\section{REFERÊNCIAS BIBLIOGRÁFICAS}

\section{APHA/AWWA/WPCF - AMERICAN PUBLIC HEALTH ASSOCIATION / AMERICAN WATER WORKS ASSOCIATION / WATER POLLUTION CONTROL FEDERATION. \\ 1985. Standard methods for the examination of water and wastewater. APHA, Washington, $16^{\text {th }}$ edition, $1268 \mathrm{p}$.}

BISTRICHI, C.A.; CARNEIRO, C.D.R.; DANTAS, A.S.L.; PONÇANO, W.L.; CAMPANHA, G.C.; NAGATA, N.;ALMEIDA, M.A.; STEIN, D.P.; MELO, M.S.; CREMONINI, O.D. 1981. Mapa geológico do Estado de São Paulo. São Paulo: IPT, Vol. II, Escala 1:500.000.

BRASIL. MINISTÉRIO DA SAÚDE. 2011. Portaria $\mathrm{n}^{\circ} 2914$ de 12 de dezembro de 2011. Dispõe sobre os procedimentos de controle e de vigilância da qualidade da água para consumo humano e seu padrão de potabilidade. Di- 
ário Oficial da União, Brasília, 14 dez. 2011, Seção 1, p. 39.

\section{CCME - CANADIAN COUNCIL OF MINISTERS} OF THE ENVIRONMENT. 1999. Community water supplies. In: Canadian environmental quality guidelines, Canadian Council of Ministers of the Environment, Winnipeg. Disponível em http://ceqg-rcqe.ccme.ca/. Acessado em 14/jun/2012.

CETESB - COMPANHIA AMBIENTAL DO ESTADO DE SÃO PAULO. 1987. Guia de coleta e preservação de amostras de água. CETESB, São Paulo, 150 p.

CETESB - Companhia Ambiental do Estado de São Paulo. 2010. Relatório de qualidade das águas subterrâneas do Estado de São Paulo: 2007-2009. CETESB, São Paulo, 258 p.

CUSTODIO, E.; LLAMAS, M.R. 1983. Hidrologia Subterránea. Omega, Barcelona, 2 ed, 2 vols.

DAEE - Departamento de Águas e Energia Elétrica. 1981a. Estudo de águas subterrâneas. Região Administrativa 4. Sorocaba. DAEE, São Paulo, 2 vols.

DAEE - Departamento de Águas e Energia Elétrica. 1981b. Estudo de águas subterrâneas. Região Administrativa 5. Campinas. DAEE, São Paulo, 2 vols.

DINIZ, H.N. 1990. Estudo hidrogeológico do Subgrupo Itararé no médio rio Tietê, município de Tietê, SP. Instituto de Geociências, Universidade de São Paulo, São Paulo, Dissertação de Mestrado, 83 p.

EZAKI, S. 2011. Hidrogeoquímica dos Aquíferos Tubarão e Cristalino na região de Salto. Instituto de Geociências, Universidade de São Paulo, São Paulo, Tese de Doutorado, 180 p.

GODOY, A.M. 1989. Caracterização faciológica, petrográfica e geoquímica dos Maciços Sorocaba e São Francisco, SP. Instituto de Geociências, Universidade de São Paulo, São Paulo, Tese de Doutorado, 220 p.

HASUI, Y.; DANTAS, A.S.L.; CARNEIRO, C.D.R.; BISTRICHI, C.A. 1981. O embasamento Pré-Cambriano e Eopaleozóico em São Paulo. In: F.F.M. de Almeida; Y. Hasui,
W.L. Ponçano; A.S.L. Dantas; C.D.R. Carneiro; M.S. de Melo; C.A. Bistrichi (Eds.) Mapa Geológico do Estado de São Paulo, escala 1:500.000. São Paulo, IPT, p. 12-45.

HASUI, Y.; FONSECA, M.J.G.; RAMALHO, R. 1984. A parte central da região de Dobramentos Sudeste e o Maciço Mediano de Guaxupé. In: C. Schobbenhaus; D. de A. Campos; G.R. Derze; H.E. Asmus (coords.) Geologia do Brasil. Brasília, DNPM, p. 307-355.

IG - INSTITUTO GEOLÓGICO. 1990. Subsídios do meio físico-geológico ao planejamento da região do Município de Sorocaba (SP). São Paulo: IG/SMA. 1v. e mapas (Relatório Técnico do Instituto Geológico).

IG - INSTITUTO GEOLÓGICO. 1991. Subsídios do meio físico-geológico ao planejamento do Município de Itu (SP). São Paulo: IG/ SMA. 2 v. (Relatório Técnico do Instituto Geológico).

IG - INSTITUTO GEOLÓGICO. 1993. Subsídios do meio físico-geológico ao planejamento do Município de Campinas (SP). Programa Cartas Geológicas e Geotécnicas para o Planejamento Ambiental na Região de Sorocaba e Campinas. São Paulo: IG/SMA, 3v.

IG - INSTITUTO GEOLÓGICO. 2009. Projeto: publicação em mídia eletrônica das cartas geológicas executadas pelo Instituto Geológico (SMA/SP) para subsidiar a ocupação e uso do meio físico na região entre Sorocaba e Campinas. Subsídios do meio físico-geológico ao planejamento do Município de Itu (SP)/ Instituto Geológico. Org. Antonio Luiz Teixeira - São Paulo: Instituto Geológico, $81 \mathrm{p}$.

JULIANI, C.; BELJAVSKIS, P. 1995. Revisão da litoestratigrafia da Faixa São Roque/Serra do Itaberaba (SP). Revista do Instituto Geológico, 16(1/2): 33-58.

JULIANI, C.; BELJAVSKIS, P.; SCHORSCHER, H.D. 1986. Petrogênese do vulcanismo e aspectos metalogenéticos associados: Grupo Serra do Itaberaba na região do São Roque - SP. In: SBG, CONGRESSO BRASILEIRO DE GEOLOGIA, 34, Goiânia, Anais, 2: 730-743. 
LOGAN, J. 1965. The interpretation of chemical analyses of water. U.S. Agency for International Development, $67 \mathrm{p}$.

ODA, G.H. 1998. Contribuição à hidrogeologia da região entre Salto de Pirapora e Itu (SP): Análise da produtividade, ocorrência e circulação das águas subterrâneas dos Sistemas Aquíferos Tubarão e Cristalino. Instituto de Geociências, Universidade de São Paulo, São Paulo, Dissertação de Mestrado, 100 p.

ODA, G.H.; MENDES, J.M.B. 1998. Aspectos geométricos, litológicos e produtivos dos Sistemas Aquíferos Tubarão e Cristalino entre as cidades de Itu e Salto de Pirapora, Estado de São Paulo, Brasil. In: ALHSUD, Congresso Latinoamericano de Hidrologia Subterránea, 4, Montevideo, Memorias, 2: 569-594.

ODA, G.H.; MENDES, J.M.B. 2000. Zoneamento da produtividade de poços na região de Sorocaba, Itu e Salto de Pirapora - Estado de São Paulo - Brasil. In: ABAS/ALHSUD/ IAH, Joint World Congress on Groundwater, 1, Fortaleza, Anais, 21 p.

PASCHOLATI, E.M. 1990. Caracterização geofísica da suíte intrusiva de Itu. Instituto de Geociências, Universidade de São Paulo, São Paulo, Tese de Doutorado, $134 \mathrm{p}$.

PEREIRA, S.Y. 1997. Proposta de representação cartográfica na avaliação para estudo de planejamento e meio ambiente. Exemplo da Região Metropolitana de Campinas-SP. Instituto de Geociências, Universidade de São Paulo, São Paulo, Tese de Doutorado, 190 p.

SÃO PAULO. 1978. Decreto ${ }^{\circ} 12.486$, de 20 de Outubro de 1978. Aprova Normas Técnicas Especiais Relativas a Alimentos e Bebidas.
SCHLUMBERGER WATER SERVICES. 2007. AquaChem v.5.1 User's Manual. Water Quality Data Analysis, Plotting, and Modeling. Waterloo, Waterloo Hydrogeologic Inc., $384 \mathrm{p}$.

SEADE - FUNDAÇÃO SISTEMA ESTADUAL DE ANÁLISE DE DADOS. 2012. Temas (Economia, População e Estatísticas Vitais, Condições de Vida, Trabalho). Disponível em http://www.seade.gov.br/. Acessado em 10/fev./2012.

SNIS - Sistema Nacional de Informações sobre Saneamento / Ministério das Cidades. 2008. Diagnóstico dos Serviços de Água e Esgoto. Disponível em http://www.snis.gov.br. Acessado em 14/jun./2011.

USDA - UNITED STATES DEPARTMENT OF AGRICULTURE. 1954. Diagnosis and Improvement of Saline and Alkaline Soils. Salinity Laboratory Staff., 160 p. (Agriculture Handbook, 60)

VIDAL, A.C. 2002. Estudo hidrogeológico do Aquífero Tubarão na área de afloramento da porção central do Estado de São Paulo. Instituto de Geociências e Ciências Exatas, UNESP, Rio Claro, Tese de Doutorado, 109 p.

VIDAL, A.C.; ROSTIROLLA, S.P.; KIANG, C.H. 2005. Análise de favorabilidade para a exploração de água subterrânea na região do Médio Tietê, Estado de São Paulo. Revista Brasileira de Geociências, 35: 475-481.

WHO - World Health Organization. 2003. Iron in drinking-water. Background document for preparation of WHO Guidelines for drinking-water quality. Geneve, (WHO/SDE/ $\mathrm{WSH} / 03.04 / 8$ ).

\section{Endereço dos autores:}

Mara Akie Iritani, Sibele Ezaki, Geraldo Hideo Oda, Luciana Martin Rodrigues Ferreira - Instituto Geológico, Secretaria do Meio Ambiente do Estado de São Paulo, Avenida Miguel Stéfano, 3900, CEP: 04301-903, Água Funda, São Paulo, SP. E-mails: mara.iritani@igeologico.sp.gov.br, sibezaki@igeologico.sp.gov.br, ghoda@igeologico.sp.gov.br, lumartin@igeologico.sp.gov.br

Sueli Yoshinaga-Pereira - Instituto de Geociências, Universidade Estadual de Campinas - UNICAMP, Rua João Pandiá Calógeras, 51, CEP: 13083-870, São Paulo, SP. E-mail: sueliyos@ige.unicamp.br 